\title{
The smoking economic control across the primary health services
}

Efraín Sánchez González ${ }^{1}$ and Fé Fernández Hernández ${ }^{2}$ *

${ }^{1}$ Faculty of Medical Sciences "10 de Octubre".

${ }^{2}$ Faculty of Medical Sciences "10 de Octubre"

*Corresponding author: Fé Fernández Hernández, Faculty of Medical Sciences "10 de Octubre".

Received date: July 02, 2020; Accepted date: July 23, 2020; Published date: July 29, 2020

Citation: Fé F Hernández, Efraín S González, (2020); The smoking economic control across the primary health services, Clinical Reviews and Clinical Trials. 2(2); DOI: 10.31579/2693-4779/014

Copyright: @ 2020 Fé Fernández Hernández, This is an open-access article distributed under the terms of the Creative Commons Attribution License, which permits unrestricted use, distribution, and reproduction in any medium, provided the original author and source are credited.

\section{Abstract}

Background: Primary health services play a decisive role for the social policy about health attention. This Public Health level attends the largest patient's numbers. The economy resources are always limited. Smoking carries to higher spend from the Public Health agree with the tobacco consumption and the smokers' number. Then, the economic smoking control since the primary health services must be a priority for the health policy.

Objective: To describe the primary public health server in the economic smoking control.

Materials and methods: Theoric methods: comparative, inductive - deductive. Empiric methods: bibliographic research.

Results: The primary public health server must be agree with capability and limitations from the public health level where works. Thus should be possible optimizate the patiens number applying for health services in superior levels.

Conclusions: The smoking economic control across the primary public health services carries to reduce the smoking economic impact over the financial management for the Public Health.

Key words: smoking, primary attention, control

\section{Background}

The primary health services play a decisive role for the social policy about health attention. This level of health services concentrates the higher number of patients. ${ }^{1}$

The economic resources are always limited. The viability of these resources is determinating the capability of attention in the different levels. Going up across the health attention levels the Public Health services become more complex and expensive too. Then, the appropriate role of the primary health services is determinant for the optimization of the Public Health services. ${ }^{2}$

Smoking carries to big spend from the Public Health budget agree with tobacco consumption and the smokers' number. That's why the smoking economic control since the primary health services must be priority of the health policy. ${ }^{3,4,5}$

The role of the health services dispenser is vital. This person is who must be leader for the community making actions for reduce the tobacco consumption and the smoking economic impact too. ${ }^{6}$

The health services dispenser for the primary health services must be sufficient since the knowledge point of view. This means that for an appropriate smoking control the health services dispenser must be protagonist for all activities about the smoking control. Also must assume several roles to obtain this objective. ${ }^{7}$

\section{Objective.}

To describe the health services dispenser role's for the primary health services in the smoking control.

\section{Materials and methods}

Theoric methods: comparative, inductive - deductive. Empiric methods: bibliographic research.

\section{Results.}

\section{The health services dispenser researching the information.}

The collection and selection of the information for the smoking economic burden research's is very important. The available and trustable information obtained from the research will determine the quality of future researches that use this information. ${ }^{8}$

The health services dispenser for the primary health services is the main responsible of these actions. It must be sufficiently capacitated front of this information research to obtain the appropriate information. ${ }^{9}$

The health services dispenser for primary health services must save a trustable and whole record about the whole population demanding the primary health services. This means that the health services dispenser must know and understand what, how, where, when and why research. All these elements will be reference for an opportune description about the health state from the population. ${ }^{10}$

The health services dispenser must understand that the information research must not be limited to the medic epidemiologic point of view. The health determinants are several and the obtained information must be minimally sufficient to get trustable economic valuation from smoking over the community health. ${ }^{11}$ 
The health services dispenser must understand which are the main variables to explain the smoking economic impact over each Public Health level and the relation saved from the population researched with each Public Health level. ${ }^{12}$

The variables to measure in each population may be determined by particular interesting. However, respect to the smoking economic burden for the Public Health, it is important identify for each patient the tobacco consumption intensity, the morbidity causes related with smoking who caused the health services demand, the frequency from the health services demand and the health costs related to each service dispensed. ${ }^{13,14,15,16}$

\section{The health services dispenser as researcher.}

Once time obtained the whole information, the health services dispenser must assume the researcher role. In this case the health services dispenser must be impartial and critical with the whole information. It must evaluate a priori the availability of possible researches based on the obtained information. Thus will be possible make a better evaluation for including secondary information from others researches. ${ }^{17}$

The health services dispenser must use several research methods agreeing with the specific objectives from the research. Means that the health services dispenser must be knower from the population demanding the health services, the true morbidity causes causing the health service demand and the research methods'. ${ }^{18}$

The use of statistical tools must be priority describing the smoking economic impact over the community health services. The health services dispenser must be sufficient to delimitate the frequency of the health services demand from a single patient by different causes. Thus will be possible research the smoking economic impact since the multi morbidity and consequences. ${ }^{19}$

This research activity must be reflexive too. The health services dispenser as researcher must understand the self capacity for researching based on the viability of economic and intellectual resources for the smoking economic research. Thus will be possible identify objective limitations against the research making. ${ }^{20}$

As part of the researching process it is important the publication of the scientific results. This action support similar research about smoking economic burden over the Public Health and similar. ${ }^{21,} 22$

\section{The health services dispenser as health promoter.}

The health services dispenser at primary level must understand that previous described roles are continue process. The obtained results in previous researches must be utilized as primaries elements to design health promotion strategies to contribute to reduce and eliminate the tobacco consumption as main cause of the smoking economic impact over the Public Health services. ${ }^{23}$

These estrategies must be valuated constantly. This means that all previous roles must be present at same time for the health services dispenser. Each Public Health level plays specific functions. In the primary health services case's is where are attended the largest patients number. The primary health services dispenser must be agree with that and contribute to reduce the patient number demanding the health services for superior levels. ${ }^{24}$

The described roles don't finish when the patient is attended by superior levels from the Public Health. The primary level is complemented with superior levels to give to the patient the whole service demanded agree with health service demand and actual capabilities. ${ }^{25}$

\section{Conclusions.}

The smoking economic control across the primary public health services carries to reduce the smoking economic impact over the financial management for the Public Health.

\section{References}

1. Linares Pérez Nivaldo. (2015) Aplicación de los enfoques de salud de la población y los determinantes sociales en Cuba. Rev Cubana Salud Pública [Internet] [citado 2019 Nov 22] ; 41( 1 )

2. García Fariñas A, Marrero Araujo M, Jiménez López G, Gálvez González AM, Hernández Crespo L, Reyes Jiménez A. (2016) Definiciones y clasificaciones básicas para el estudio de los costos en salud. Revista INFODIR [revista en Internet]. [citado 2019 Nov 22];0(23):[aprox. 2 p.].

3. Fernández Hernández F., Sánchez González E. (2017) Impacto del tabaquismo en el presupuesto sanitario de Cuba 1997-2014. Revista del Hospital Psiquiátrico de La Habana. Vol. 14, No. 2 [citado 2019 Dic 13]

4. Fernández Hernández F, Sánchez González E. (2017) Carga epidemiológica vs carga económica del tabaquismo por morbilidad. Rev. Ciencias Médicas [Internet]. Abr [citado 2019 Oct 3] ; 21( 2 ): 60-66.

5. Sánchez González E, Fernández Hernández F. (2017) El rol de las autoridades fiscales en el control del tabaquismo. Rev Ciencias Médicas [Internet]. Jun [citado 2019 Sep 25] ; 21( 3 ): 62-67.

6. Bonet Gorbea M, Varona Pérez P, Chang La Rosa M, García Roche RG, Suárez Medina R, Arcia Montes de Oca N, et. al. (2014). III Encuesta de factores de riesgo y actividades preventivas de enfermedades no transmisibles. Cuba 2010-2011. [Internet]. La Habana: Editorial Ciencias Médicas; [Citado el 16 de febrero de 2020]

7. Fernández Hernández F., Sánchez González E. (2019). Diploma Course: "The Social Smoking Cost in the National Economy", A Necessary and Appliable Tool. [Internet]. Ago [citado 2019 Dic 25]. DOI: 10.24966/CMPH-1978/100052

8. Arredondo A, Recaman AL, Pinzon C, Azar A. (2018). Financial consequences from smoking-related diseases in middle-income countries: Evidence and lessons from Mexico. Int J Health Plann Mgmt.33:e454-e463.

9. León Román CA, Morgado Gutiérrez FC, Vázquez Borges B. (2017) Adicción al tabaco en estudiantes de enfermería técnica. Revista Cubana de Enfermería [revista en Internet]. [citado 2018 Dic 13];33(4):[aprox. 0 p.].

10. Abascal Winston, Lorenzo Ana. (2017). Impacto de la política de control de tabaco en población adolescente en Uruguay. Salud pública Méx [revista en la Internet]. [citado 2019 Ago 08] ; 59( Suppl 1 ): 40-44.

11. González Menéndez R. (2017). Tácticas para vencer las drogas blandas y duras. Consejos de un viejo adictólogo. Santiago de Cuba: Editorial Oriente.

12. Fernández Hernández F., Sánchez González E. (2019). La carga económica del tabaquismo(2019). Barcelona: Editorial Académica Española.

13. Fernández Hernández F., Sánchez González E. (2019). Estimating the economic burden attributable to some risk factor. Journal of Clinical Investigation and Studies. 
[Internet] [citado 2019 Oct 06]; (2): 1-2. Doi: 10.15761/JCIS.1000121

14. Fernández Hernández F., Sánchez González E. (2017) Pérdida de productividad por el consumo de cigarrillos en la jornada laboral. Revista Cubana de Salud y Trabajo; 18(3):9-12.

15. Fernández Hernández F, Sánchez González E. (2018) Algorithm to calculate the smoking economical burden in active and passive smokers. MOJ Toxicol; 4(6):373-375. DOI: 10.15406/mojt.2018.04.00131.

16. Fernández Hernández F, Sánchez González E. (2019). The socioeconomic inequity attributable to smoking. Journal of Medical Practice and Review [Internet] [citado 2019 Jun 15]; 3(6): 559 - 562.

17. Marimón Torres Eugenia Rita, Orraca Castillo Odalys, Casanova Moreno María Caridad, Paredes Díaz Roberto, (2013) Mendoza Ferreiro Maricel. Prevalencia de factores de riesgo de enfermedades no transmisibles. Rev Ciencias Médicas [Internet]. Abr [citado 2019 Nov 21] ; 17( 2 ): 2-12.

18. Abascal Winston, Lorenzo Ana. (2017) Impacto de la política de control de tabaco en población adolescente en Uruguay. Salud pública Méx [revista en la Internet]. [citado 2019 Ago 08] ; 59( Suppl 1 ): 40-44.

19. Sánchez González E, Fernández Hernández F. (2018) La relación entre la política tributaria y el control del tabaquismo en Cuba. CCM [Internet]. Jun [citado 2019 Dic 13] ; 22( 2 ): 238-249.
20. Lightwood J, Glantz SA (2013) The Effect of the California Tobacco Control Program on Smoking Prevalence, Cigarette Consumption, and Healthcare Costs: 1989-2008. PLoS ONE 8(2): e47145. doi:10.1371/journal.pone.0047145.

21. Pupo Ávila NL, Hechavarría Toledo S., Anabel Lozano L. (2016) Caracterización de las publicaciones sobre tabaquismo en revistas científicas cubanas (2005-2014). Revista Cubana de Salud Pública.;42(3):375-384.

22. Plá García Avelino, Elizarde Gálvez Miriam Gloria, Cárdenas Friera Evelio, Solares Carreño Juan Carlos, (2016) Nieves Sardiñas Blanca Nieves. Tabaquismo: valores e integralidad. Rev.Med.Electrón. [Internet]. Jun [citado 2018 Dic 13] ; 38( 3 ): 460-469.

23. Plamondon, Geneviève, Guindon, G Emmanuel y Paraje, Guillermo. (2017), Exposición a la publicidad de tabaco y consumo de tabaco en adolescentes en América del Sur. Salud Pública de México [online]. v. 59, n. Suppl 1 [Accedido 13 Deciembre 2018] , pp. 80-87.

24. Valdivia C Gonzalo. (2015) Hacia el control radical de las enfermedades respiratorias: un alto en el camino. Rev. chil. enferm. respir. [Internet]. Mar [citado 2018 Dic 13] ; 31( 1 ): 5-7.

25. Etienne, Carissa F. (2018) Cuba hacia la Salud Universal. Revista Panamericana de Salud Pública [online], v. 42 [Accedido 13 Deciembre 2019], e64. 